\title{
INVASION IMPACT OF Artocarpus heterophyllus LAM. (Moraceae) AT THE EDGE OF AN ATLANTIC FOREST FRAGMENT IN THE MUNICIPALITY OF RIO DE JANEIRO, BRAZIL
}

\author{
IMPACTO DA INVASÃO DE Artocarpus heterophyllus LAM. (Moraceae) NA BORDA \\ DE UM FRAGMENTO DE MATA ATLÂNTICA NA CIDADE DO RIO DE JANEIRO, \\ BRASIL
}

\author{
Welington Kiffer de FREITAS ${ }^{1}$; Luís Mauro Sampaio MAGALHÃES ${ }^{2}$; \\ Alexander Silva de Resende ${ }^{3}$; Felipe da Costa BRASIL ${ }^{1}$; Lise da Rocha VIVÈS ${ }^{1}$; \\ Marco Aurélio Soares PINHEIRO ${ }^{2}$; Pedro Lima FILHO ${ }^{2}$; Rômulo Vinicius LUZ ${ }^{1}$ \\ 1. Universidade Federal Fluminense, Volta Redonda, RJ, Brasil. wkfreitas@gmail.com; 2. Universidade Federal Rural do Rio de \\ Janeiro, Seropédica, RJ, Brasil; 3. Empresa Brasileira de Pesquisa Agropecuária, Seropédica, RJ, Brasil.
}

\begin{abstract}
The Atlantic Forest is reduced to less than $20 \%$ of its original area, but it still protects an important biological heritage. Forest fragmentation makes the environment more susceptible to invasive species occupation. Jackfruit (Artocarpus heterophyllus) was introduced into Brazil in the seventeenth century; and in the second half of the twentieth century, its natural regeneration increased the density of individuals, compromising the recruitment of many native species. This study investigated the impact of $A$. heterophyllus invasion on the diversity and tree structure component at the edge of an Atlantic Forest fragment, in Rio de Janeiro (Brazil). Two transect-type plots were set up with $10 \mathrm{~m} \times 100 \mathrm{~m}\left(1,000 \mathrm{~m}^{2}\right)$, being divided into 10 subplots of $10 \mathrm{~m} \times 10 \mathrm{~m}$, with a total sampling area of $2,000 \mathrm{~m}^{2}$. Trees with a diameter at breast height $(\mathrm{DBH})$ equals to or greater than $5 \mathrm{~cm}$ were tagged and $\mathrm{DBH}$ and total height measured. The following phytosociological parameters were estimated: Frequency (F), Density (D), Dominance (Do), Importance (IV) and Coverage (CV) Values. In total, 191 tree individuals were sampled. Invasive species made up more than $35 \%$ of the entire vegetation structure in the studied environment, ending in first place in terms of Importance Value (IV $=$ $35.62 \%)$. Low floristic wealth seems to have favored the A. heterophyllus invasion process in the community, showing the need for an effective control of the species for the native genetic heritage protection.
\end{abstract}

KEYWORDS: Jackfruit. Phytosociology. Horizontal structure. Dominance.

\section{INTRODUCTION}

The Atlantic Forest encompasses 17 Brazilian states, with an original area of about $1,300,000$ square kilometers, extending from the state of Rio Grande do Norte to the state of Rio Grande do Sul, also covering part of Argentina and Paraguay territories (LIMA; CAPOBIANCO, 1997; MAGALHÃES; FREITAS, 2013). It is currently estimated that nearly 11 to $16 \%$ of its original cover is maintained (RIBEIRO et al., 2009).

Nowadays, the diversity of the Atlantic Forest is under serious threat due to an intense human occupation, to which this biome has gone through. The state of Rio de Janeiro still keeps near $18.6 \%$ of its original forest covers, which are mainly located within Conservation Units and in areas difficult to access (SANTANA et al., 2015).

In 2000, the Atlantic Forest was considered as the second most threatened biome worldwide, and one among the 35 global 'hotspots' of biodiversity by the nonprofit environmental organization Conservation International, since it owns a high biodiversity with high rates of endemism in great threat (MYERS et al., 2005; WILLIANS et al., 2011). More than 15,000 plant species occur within its domain, of which about 7,000 have some degree of endemism (STEHMANN et al., 2009).

The fragility of this biome provides the occurrence of a threatening phenomenon to its biodiversity, which is the biological invasion. According to Ziller and Galvão (2002), the biological invasion is an introduction process and, consequently, an adaptation of species that are not naturally found in a certain ecosystem but naturalize themselves, and begin to cause changes in the local ecological processes.

Lake and Leishman (2003) emphasized features that are likely associated with an invasive behavior of plants, such as leaf surface area, texture and hairiness, seed mass, growth form, dispersion mode, vegetative propagation capacity, flowering time, and canopy height.

Each species ecological importance within a community is associated with its ability to promote interspecific interactions (HURLBERT, 1971). Indeed, biological contamination occurs because 
invasive species show a minimum of interactions since they have no relationship with the organisms living in the new environment.

As stated by Pysek (1995), an invasive species is an exotic whose distribution and/or abundance are in an increasing process. According to Parker et al. (1999), biological invasions can cause impacts at different levels, including effects on individuals (e.g. mortality rates and growth), genetics (e.g. hybridization), population dynamic (abundance, population growth, and extinction), community (species richness, diversity, and trophic structure), and ecosystem processes (nutrient availability, productivity, and disturbance regime). As reported by Kanashiro (2003), species known as 'invasive', are nowadays regarded as the world's second-largest threat to biodiversity.

One of the species that has shown an invasive behavior in the Atlantic Forest is Artocarpus heterophyllus Lam., commonly known as jackfruit or jack tree (FABRICANTE et al., 2012). This species was introduced into Brazil by the Portuguese Royalty, in the seventeenth century, due to a mercantilist policy aiming to acclimatize plants and spices from Asia (PEREIRA; KAPLAN, 2013). The jack tree has become part of a list of alien species widely used in landscaping projects by Auguste Glaziou, who was hired by D. Pedro II, in the mid-nineteenth century, to serve as director of the Rio de Janeiro's division of parks and gardens, in Boa Vista and Campo de Santana (SANTOS et al., 2008). Furthermore, at that time, the species joined the list of trees used to recover part of the massif of Tijuca (RJ), exhausted by coffee and sugarcane monoculture (DEAN, 1996). This species has easily adapted to Brazil by several factors, such as a high annual production of fruit and absence of specific predators, besides serving as a food source for several species of native animals (PEREIRA; KAPLAN, 2013). In the early twentieth century, jack trees were used in gardens, farms, country houses, and orchards of this city, wherein its fruit is commonly found in small shops (grocery stores), local markets, street vendors and in free markets (MAGALHÃES et al., 2015).

Apparently, the presence of this species in Brazil has not been a problem until the second half of the twentieth century. However, in the 1970's to 80 's of the last century, some protected areas in Rio de Janeiro city, like Tijuca National Park, showed a fast natural regeneration of jack trees, expanding increasingly and hindering the richness of native species. Thenceforth jack trees began to show a typical behavior of invasive alien species (BYERS et al., 2002; ABREU; RODRIGUES, 2010; BERGALLO et al., 2016). This occupation weakens the efforts taken by the society to protect forest remnants of an ecosystem with great ecological value as fragments of the Atlantic Forest.

This study aimed to analyze aspects of the structure and diversity at the edge of a fragment invaded by $A$. heterophyllus, in the Mendanha Municipal Natural Park (MMNP), on the westside of Rio de Janeiro - RJ, Brazil.

\section{MATERIAL AND METHODS}

\section{Study area}

This study was conducted at the edge of a forest fragment invaded by A. heterophyllus (1 hectare). It is located in the Mendanha Municipal Natural Park (MMNP), in Bangu - westside of Rio de Janeiro (RJ), Brazil $\left(22^{\circ} 55 \mathrm{~S}\right.$ and $\left.43^{\circ} 30 \mathrm{~W}\right)$, with an area of 1,323,47 ha (TOMIAZZI et al., 2006) (Figure 1).

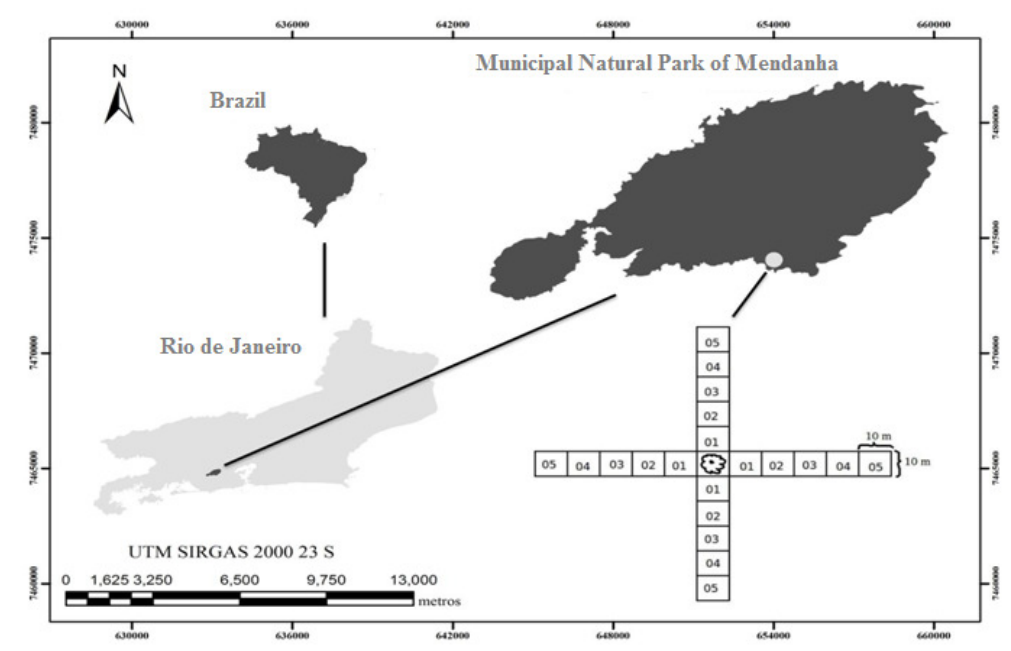

Figure 1. Location of the MMNP, Rio de Janeiro, Brazil. Source: Landscapes Management Laboratory - DCA/IF/UFRRJ 


\section{Methodology}

In this study, the sampling was made in tracks (IBGE, 1992), using transect-type plots of $10 \mathrm{~m} \mathrm{x}$ $100 \mathrm{~m}\left(1,000 \mathrm{~m}^{2}\right)$. Across the entire study area, two transects were set up perpendicularly, one in the North-South direction and the other in the EastWest direction. Each one was divided into 10 subplots of $10 \mathrm{~m} \mathrm{x} 10 \mathrm{~m}$ (Fig. 1).

Within the subplots $(10 \mathrm{~m} \times 10 \mathrm{~m})$, all tree individuals with circumference at breast height $(\mathrm{CBH})$, or at $1.30 \mathrm{~m}$ above the soil, $\geq 15.7 \mathrm{~cm}$ (or $\mathrm{DBH} \geq 5 \mathrm{~cm}$ ), including standing dead trees, were tagged with numbered aluminum tags $(3 \mathrm{~cm} \times 3$ $\mathrm{cm}$ ), in intaglio printing, with the aid of metal numbers.

Biometric data (total height and $\mathrm{CBH}$ ) were obtained and registered in field records. In the case of forked trees, all stems emerging from the soil were individually measured, as well as the stem forked below the $\mathrm{DBH}$, considering only those stems that met the inclusion criteria above.

For each individual tree immediately unidentified, morphological characteristics were noted, such as the rhytidome color, exudates (latex, sap, resin, and gum), odor, or other traits able to assist in identification, such as popular name.

Between March and July 2012, representative samples of morphospecies were collected for identification and deposited in an herbarium. Sampling was carried out using longreach branch pruners.

The specimens were placed between layers of newspapers and pressed in an herbarium press, remaining preserved in alcohol during field stay. At the laboratory, all the collected botanical material was dried in an oven for further identification through comparisons of their morphological characters to those of exsiccates available in the Herbarium of the Federal Rural University of Rio de Janeiro (UFRRJ), by means of bibliographic consultation and expert support.

In addition, species and individuals found within the examined fragment were classified according to successional stages (pioneer, early secondary, late secondary, and climax) (BUDOWSKI, 1965), besides unclassified ones.

Validation of species names and standardization of botanical synonyms were ascertained by consulting the website Flora Brasil (2015). Taxa were classified according to the Angiosperm Phylogeny Group (APG III, 2009), except for Fabaceae family which was based on Cronquist (1981), considering the subfamilies Caesalpinioideae, Faboideae, and Mimosoideae.
Spatial distribution of A. heterophyllus trees was established by the use of McGinnies' index (IGA) (MC GINNIES, 1934). In this study, the following phytosociological parameters were considered: Frequency (F), Density (D), Dominance (Do), Coverage and Importance Values (CV and IV) (MULLER-DOMBOIS; ELLENBERG, 1974). All calculations were processed through Mata Nativa 3 software (CIENTEC, 2006).

\section{RESULTS}

At the edge of the examined forest fragment, 191 tree individuals were found, belonging to 20 families, 27 genera, and 28 species, also disregarding the unidentified and dead individuals (Tables 1 and 2).

Nearly $15 \%$ of the individuals were described only as morphospecies, families, or genera, given the lack of plant sources for identification during fieldworks, such as reproductive material (flowers and fruits), which is the basis for determining taxonomy.

Of the 191 sampled individuals, 114 belonged to only three botanical families. Jointly, Moraceae (67), Meliaceae (30), and Fabaceae (17) accounted for almost $60 \%$ of the total individuals. The other 77 individuals were distributed among the other families (Table 1).

Families that stood out in number of species were Fabaceae and Myrtaceae, with three species each, followed by Bignoniaceae, Caricaceae, Melastomataceae and Meliaceae, each featuring two species.

With great expressiveness in the studied environment, A. heterophyllus stood out by reaching a McGinnies' index (IGA) of 2.08, showing a trend to clustering. The basal area was $25.97 \mathrm{~m}^{2} \mathrm{x} \mathrm{ha} \mathrm{a}^{-1}$.

The community showed greater participation, both for individuals (39\%) and species (39\%), of organisms belonging to the ecological group of early secondary (Figure 2). 
Table 1. Floristic list of tree species from the edge of an Atlantic Forest fragment located in the MMNP, Rio de Janeiro city (RJ), Brazil. Wherein: PI = pioneer species; ES = early secondary species; LS = late secondary species; $\mathrm{UN}=$ unclassified species; $\mathrm{N}=$ native from Brazilian flora; $\mathrm{EX}=$ exotic species; $\mathrm{EN}=$ endemic to the Atlantic Forest; NE $=$ non-endemic to the Atlantic Forest

\begin{tabular}{|c|c|c|c|}
\hline Family & Scientific Name & $\begin{array}{c}\text { Ecological } \\
\text { Group }\end{array}$ & $\begin{array}{c}\text { Origin / } \\
\text { Endemism }\end{array}$ \\
\hline ANACARDIACEAE & Astronium graveolens Jacq. & ES & N/NE \\
\hline ANNONACEAE & Guatteria candolleana Schltdl. & ES & N/EN \\
\hline APOCYNACEAE & Tabernaemontana laeta Mart. & LS & $\mathrm{N} / \mathrm{NE}$ \\
\hline BIGNONIACEAE & $\begin{array}{l}\text { Jacaranda macrantha Cham. } \\
\text { Sparattosperma leucanthum (Vell.) K. } \\
\text { Schum. }\end{array}$ & $\begin{array}{l}\text { ES } \\
\text { P }\end{array}$ & $\begin{array}{l}\mathrm{N} / \mathrm{NE} \\
\mathrm{N} / \mathrm{NE}\end{array}$ \\
\hline CANNABACEAE & Trema micrantha (L. Blumen) & $\mathrm{P}$ & $\mathrm{N} / \mathrm{NE}$ \\
\hline CARICACEAE & Carica papaya $\mathrm{L}$. & $\mathrm{P}$ & EX \\
\hline & Jacaratia spinosa (Aubl.) A. DC. & $\mathrm{P}$ & N/NE \\
\hline CELASTRACEAE & Maytenus obtusifolia Mart. & LS & $\mathrm{N} / \mathrm{NE}$ \\
\hline ERYTHROXYLACEAE & Erythroxylum pulchrum A. St.-Hil. & ES & N/EN \\
\hline FABACEAE & $\begin{array}{l}\text { Apuleia leiocarpa (Vogel) J.F. Macbr. } \\
\text { Piptadenia gonoacantha (Mart.) J.F. } \\
\text { Macbr. }\end{array}$ & $\begin{array}{l}\text { LS } \\
\mathrm{P}\end{array}$ & $\begin{array}{l}\mathrm{N} / \mathrm{NE} \\
\mathrm{N} / \mathrm{NE}\end{array}$ \\
\hline & Pseudopiptadenia sp. & ES & N/EN \\
\hline LAURACEAE & $\begin{array}{l}\text { Nectandra membranacea (Sw.) Griseb. } \\
\text { Ocotea } \text { sp. }\end{array}$ & $\begin{array}{l}\text { ES } \\
\text { LS }\end{array}$ & $\begin{array}{c}\mathrm{N} / \mathrm{NE} \\
\mathrm{N}\end{array}$ \\
\hline MELASTOMATACEAE & $\begin{array}{l}\text { Miconia cinnamomifolia (DC.) Naudin } \\
\text { Miconia sp. }\end{array}$ & $\begin{array}{l}\mathrm{P} \\
\mathrm{P}\end{array}$ & $\begin{array}{c}\text { N/EN } \\
\mathrm{N}\end{array}$ \\
\hline MELIACEAE & $\begin{array}{l}\text { Cabralea canjerana (Vell.) Mart. } \\
\text { Guarea guidonia (L.) Sleumer }\end{array}$ & $\begin{array}{l}\mathrm{ES} \\
\mathrm{ES}\end{array}$ & $\begin{array}{l}\mathrm{N} / \mathrm{NE} \\
\mathrm{N} / \mathrm{NE}\end{array}$ \\
\hline MORACEAE & Artocarpus heterophyllus Lam. & $\mathrm{UN}$ & EX \\
\hline MYRTACEAE & $\begin{array}{l}\text { Eugenia sp. } \\
\text { Marlierea glazioviana Kiaersk. } \\
\text { (O.Berg) Loefgr. \& Everett } \\
\text { Myrtaceae } 2\end{array}$ & $\begin{array}{l}\text { LS } \\
\text { UN }\end{array}$ & $\begin{array}{c}\text { N/EN } \\
\text { UN }\end{array}$ \\
\hline NYCTAGINACEAE & Guapira opposita (Vell.) Reitz & ES & $\mathrm{N} / \mathrm{NE}$ \\
\hline PHYTOLACCACEAE & Gallesia integrifolia (Spreng.) Harms & ES & $\mathrm{N} / \mathrm{NE}$ \\
\hline RUBIACEAE & Psychotria leiocarpa Cham. \& Schltdl. & ES & $\mathrm{N} / \mathrm{NE}$ \\
\hline SALICACEAE & Casearia sylvestris $\mathrm{Sw}$. & $\mathrm{P}$ & $\mathrm{N} / \mathrm{NE}$ \\
\hline SAPINDACEAE & Cupania vernalis Cambess & $\mathrm{P}$ & $\mathrm{N} / \mathrm{NE}$ \\
\hline URTICACEAE & Cecropia sp. & $\mathrm{P}$ & $\mathrm{N} / \mathrm{NE}$ \\
\hline UNDETERMINED & - & UN & UN \\
\hline
\end{tabular}




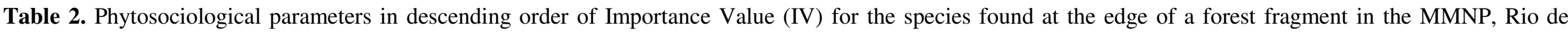
Janeiro (RJ), Brazil.

\begin{tabular}{|c|c|c|c|c|c|c|c|c|c|c|c|c|}
\hline Scientific Name & $\mathbf{N}$ & $\mathbf{B A}$ & AD & RD & $\mathbf{A F}$ & RF & ADo & RDo & $\mathbf{C V}$ & CV (\%) & IV & IV (\%) \\
\hline Artocarpus heterophyllus Lam. & 67 & 5.194 & 335 & 35.08 & 80 & 14.29 & 25.969 & 57.49 & 92.57 & 46.28 & 106.855 & 35.62 \\
\hline Guarea guidonia (L.) Sleumer & 27 & 1.278 & 135 & 14.14 & 60 & 10.71 & 6.39 & 14.15 & 28.283 & 14.14 & 38.997 & 13 \\
\hline Psychotria leiocarpa Cham. \& Schltdl. & 11 & 0.149 & 55 & 5.76 & 55 & 9.82 & 0.744 & 1.65 & 7.405 & 3.7 & 17.227 & 5.74 \\
\hline Pseudopiptadenia sp. & 8 & 0.223 & 40 & 4.19 & 35 & 6.25 & 1.113 & 2.46 & 6.652 & 3.33 & 12.902 & 4.3 \\
\hline Piptadenia gonoacantha (Mart.) J.F. Macbr. & 6 & 0.444 & 30 & 3.14 & 25 & 4.46 & 2.22 & 4.91 & 8.056 & 4.03 & 12.52 & 4.17 \\
\hline Gallesia integrifolia (Spreng.) Harms & 4 & 0.374 & 20 & 2.09 & 20 & 3.57 & 1.868 & 4.13 & 6.229 & 3.11 & 9.8 & 3.27 \\
\hline Guatteria candolleana Schltdl. & 6 & 0.076 & 30 & 3.14 & 20 & 3.57 & 0.378 & 0.84 & 3.979 & 1.99 & 7.55 & 2.52 \\
\hline Dead & 4 & 0.165 & 20 & 2.09 & 20 & 3.57 & 0.825 & 1.83 & 3.921 & 1.96 & 7.493 & 2.5 \\
\hline Erythroxylum pulchrum A.St.-Hil. & 5 & 0.117 & 25 & 2.62 & 20 & 3.57 & 0.584 & 1.29 & 3.911 & 1.96 & 7.482 & 2.49 \\
\hline Ocotea sp. 2 & 7 & 0.044 & 35 & 3.66 & 15 & 2.68 & 0.218 & 0.48 & 4.147 & 2.07 & 6.826 & 2.28 \\
\hline Guapira opposita (Vell.) Reitz & 4 & 0.182 & 20 & 2.09 & 15 & 2.68 & 0.909 & 2.01 & 4.106 & 2.05 & 6.784 & 2.26 \\
\hline Tabernaemontana laeta Mart. & 4 & 0.126 & 20 & 2.09 & 15 & 2.68 & 0.632 & 1.4 & 3.493 & 1.75 & 6.171 & 2.06 \\
\hline Apuleia leiocarpa (Vogel) J.F. Macbr. & 3 & 0.142 & 15 & 1.57 & 15 & 2.68 & 0.712 & 1.58 & 3.147 & 1.57 & 5.826 & 1.94 \\
\hline Miconia cinnamomifolia (DC.) Naudin & 2 & 0.219 & 10 & 1.05 & 10 & 1.79 & 1.096 & 2.43 & 3.475 & 1.74 & 5.26 & 1.75 \\
\hline Cabralea canjerana (Vell.) Mart. & 3 & 0.084 & 15 & 1.57 & 15 & 2.68 & 0.42 & 0.93 & 2.501 & 1.25 & 5.179 & 1.73 \\
\hline Trema micrantha (L.) Blume & 4 & 0.011 & 20 & 2.09 & 15 & 2.68 & 0.054 & 0.12 & 2.213 & 1.11 & 4.891 & 1.63 \\
\hline Astronium graveolens Jacq. & 3 & 0.014 & 15 & 1.57 & 15 & 2.68 & 0.072 & 0.16 & 1.731 & 0.87 & 4.409 & 1.47 \\
\hline Marlierea glazioviana Kiaersk. & 3 & 0.009 & 15 & 1.57 & 15 & 2.68 & 0.044 & 0.1 & 1.669 & 0.83 & 4.348 & 1.45 \\
\hline Sparattosperma leucanthum (Vell.) K. Schum. & 2 & 0.056 & 10 & 1.05 & 10 & 1.79 & 0.282 & 0.62 & 1.672 & 0.84 & 3.458 & 1.15 \\
\hline Jacaranda macrantha Cham. & 2 & 0.022 & 10 & 1.05 & 10 & 1.79 & 0.112 & 0.25 & 1.296 & 0.65 & 3.081 & 1.03 \\
\hline Cupania vernalis Cambess. & 2 & 0.02 & 10 & 1.05 & 10 & 1.79 & 0.1 & 0.22 & 1.269 & 0.63 & 3.055 & 1.02 \\
\hline Eugenia sp. & 2 & 0.008 & 10 & 1.05 & 10 & 1.79 & 0.041 & 0.09 & 1.139 & 0.57 & 2.924 & 0.97 \\
\hline Undetermined 1 & 2 & 0.015 & 10 & 1.05 & 5 & 0.89 & 0.073 & 0.16 & 1.209 & 0.6 & 2.102 & 0.7 \\
\hline Undetermined 2 & 1 & 0.034 & 5 & 0.52 & 5 & 0.89 & 0.171 & 0.38 & 0.901 & 0.45 & 1.794 & 0.6 \\
\hline Miconia sp. & 1 & 0.006 & 5 & 0.52 & 5 & 0.89 & 0.032 & 0.07 & 0.595 & 0.3 & 1.488 & 0.5 \\
\hline Nectandra membranaceae (Sw.) Griseb. & 1 & 0.004 & 5 & 0.52 & 5 & 0.89 & 0.02 & 0.04 & 0.568 & 0.28 & 1.461 & 0.49 \\
\hline Casearia sylvestris $\mathrm{Sw}$. & 1 & 0.004 & 5 & 0.52 & 5 & 0.89 & 0.018 & 0.04 & 0.564 & 0.28 & 1.457 & 0.49 \\
\hline Undetermined 3 & 1 & 0.004 & 5 & 0.52 & 5 & 0.89 & 0.018 & 0.04 & 0.562 & 0.28 & 1.455 & 0.49 \\
\hline Maytenus obtusifolia Mart. & 1 & 0.003 & 5 & 0.52 & 5 & 0.89 & 0.014 & 0.03 & 0.555 & 0.28 & 1.448 & 0.48 \\
\hline Cecropia sp. & 1 & 0.002 & 5 & 0.52 & 5 & 0.89 & 0.01 & 0.02 & 0.546 & 0.27 & 1.439 & 0.48 \\
\hline Jacaratia spinosa (Aubl.) A. DC. & 1 & 0.002 & 5 & 0.52 & 5 & 0.89 & 0.01 & 0.02 & 0.546 & 0.27 & 1.439 & 0.48 \\
\hline Myrtaceae 2 & 1 & 0.002 & 5 & 0.52 & 5 & 0.89 & 0.01 & 0.02 & 0.546 & 0.27 & 1.439 & 0.48 \\
\hline Carica papaya $\mathrm{L}$. & 1 & 0.002 & 5 & 0.52 & 5 & 0.89 & 0.01 & 0.02 & 0.545 & 0.27 & 1.438 & 0.48 \\
\hline Total & 191 & 9.034 & 955 & 100 & 560 & 100 & 45.17 & 100 & 200 & 100 & 300 & 100 \\
\hline
\end{tabular}

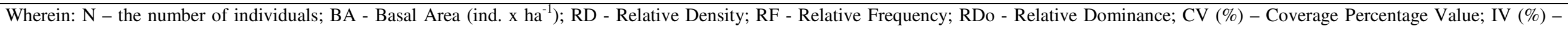
Importance Percentage Value. 


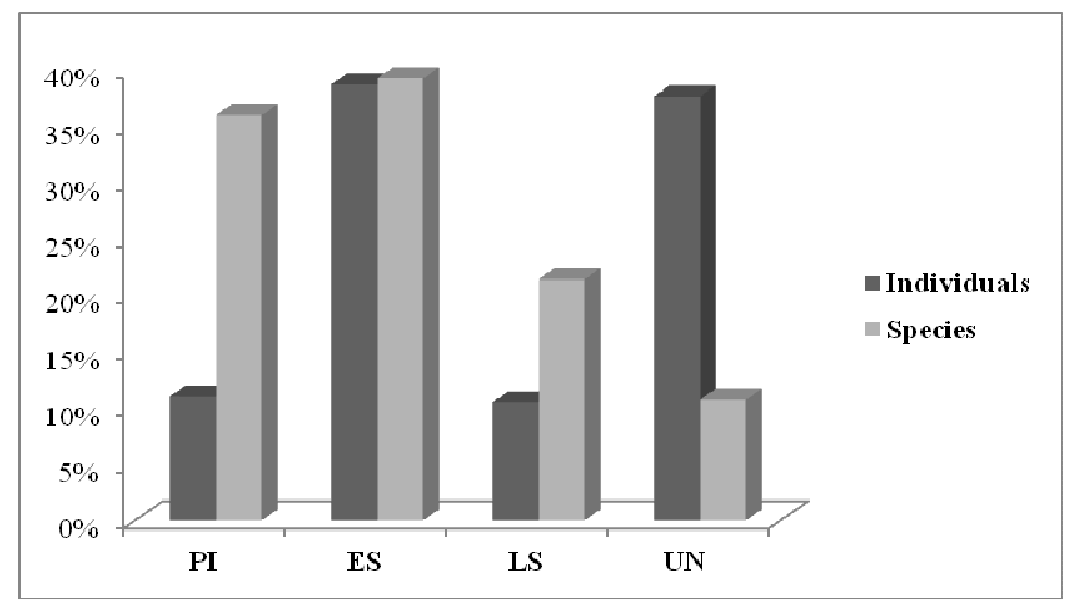

Figure 2. Frequency distribution of ecological groups of individuals and species found in the edge of a forest fragment in the MNPM, RJ, Brazil. Where: $\mathrm{P}$ = pioneer species; $\mathrm{ES}=$ early secondary species; $\mathrm{LS}=$ late secondary species; $\mathrm{UN}=$ unclassified species.

Table 2 shows that A. heterophyllus excelled all other species within the community, totaling $35.62 \%$ of total IV, followed by Guarea guidonea $(\mathrm{IV}=13 \%)$.

Diameter distribution, illustrated in Figure 3, showed a typical pattern for uneven-aged tropical forest stands, in inverted-J-shape, indicating that tree recruitment rates tend to offset mortality over time (DURIGAN, 2009). As regards the distribution of diameter of native species (Figure 3), perhaps the competition with $A$. heterophyllus provided an imbalance, mainly for larger trees (40.0 to $44.9 \mathrm{~cm})$. However, such inverted-J-shape behavior (Figure 3) suggested a great self-regeneration capacity and maintenance of density levels of A. heterophyllus population.

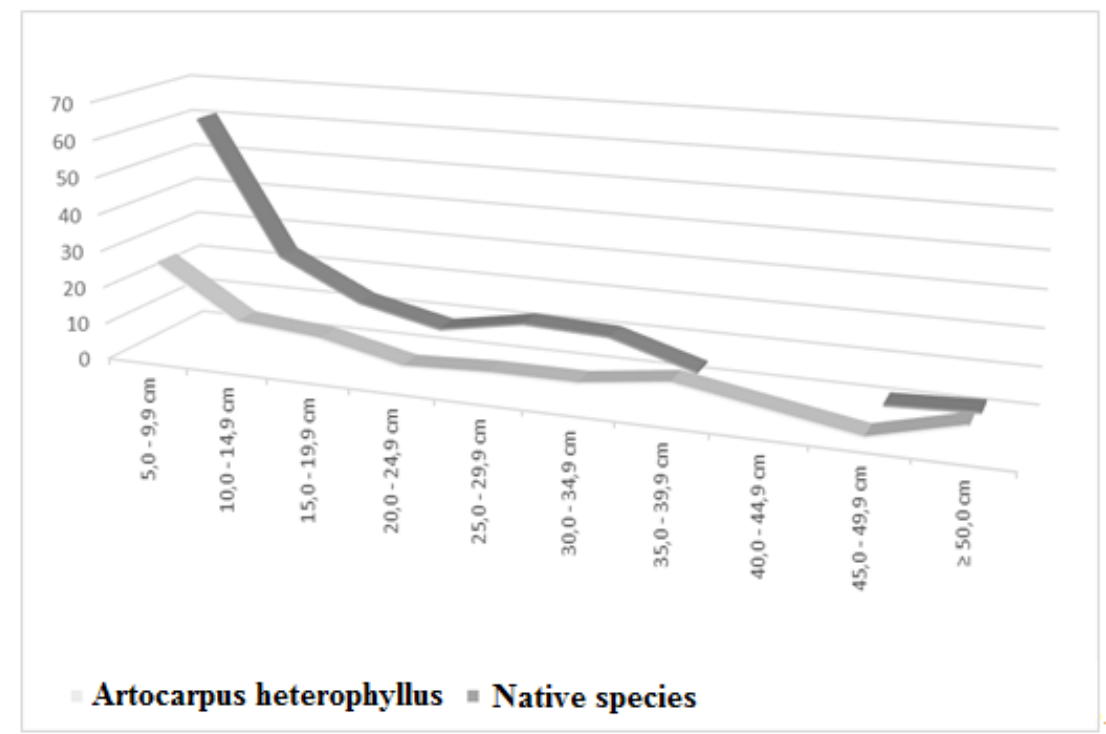

Figure 3. Frequency distribution of diameter classes of the sampled tree individuals at the edge of a forest fragment in the MMNP, Rio de Janeiro (RJ), Brazil.

\section{DISCUSSION}

This study recorded a few individuals identified only by morpho-species, families, or genera, given the lack of plant reproductive parts during fieldworks (flowers and fruits), which serve as the basis for determining taxonomy.

In the Atlantic Forest, Fabaceae and Myrtaceae families are considered the most representative in species richness (OLIVEIRAFILHO; FONTES, 2000), as proven by this study. Nevertheless, when analyzing the number of individuals per family, Moraceae family stood out because of its high number of A. heterophyllus individuals.

The species A. heterophyllus is characterized as an introduced plant species performing aggressively as a biological invader 
since it had already been pointed out in different studies carried out in the Brazilian Atlantic Forest (ABREU; RODRIGUES, 2010; FABRICANTE et al., 2012; CRUZ et al., 2013; MAGALHÃES et al., 2015; BERGALLO et al., 2016).

According to Cruz et al. (2013), A. heterophyllus may have three to four reproductive events each year, with a single individual responsible for about 100 fruits in each reproductive phase, with seeds showing high germination rates, especially in edge environments (ABREU; RODRIGUES, 2010). These authors also highlighted the low palatability of its vegetative parts, reducing herbivory, besides the absence of predators able to regulate its populations within the ecosystem, according to the Enemy Release Hypothesis (KEANE; CRAWLEY, 2002; SAX; BROWN, 2000). Cunha et al. (2006) and Mello et al. (2015) emphasized the role of native fauna (spiny-rat, agoutis, opossums, and primates) as a potential spreader of propagules. According to these authors, a protocooperation relationship is established between A. heterophyllus and certain primate species, also exotic in the Atlantic Forest of the southeastern Brazil, as Callithrix jacchus (originally from the northeastern Atlantic Forest) and Callithrix penicillata (from the Cerrado biome), which also have no specific predators within this biome. Such relationship relies on the sense that these animals would facilitate dispersion of $A$. heterophyllus seeds by peeling fruit searching for pulp which surrounds the seeds. These factors reveal the high invading potential of this species, which could cause flora homogenization in important remnants of the Atlantic Forest.

Invasive plants can cause significant changes in fundamental properties that may breach ecological thresholds such as nutrient cycling, structure, dominance, density, distribution, and species functions, in addition to interfering with evolutionary processes and relationships between pollinators and plants (ZILLER, 2006).

As stated by Abreu and Rodrigues (2010), biological invasion problem has been every day more critical in Strictly Protected Conservation Units, mainly Parks, Biological Reserves, and Ecological Stations, which are legally protected areas and where human interventions are more restrictive (BRAZIL, 2000). Recent studies have pointed to problems caused by A. heterophyllus in some Conservation Units of the Rio de Janeiro state as the MMNP (MAGALHÃES et al., 2015), the Tijuca National Park (ABREU; RODRIGUES, 2010), the Atalaia Municipal Park, in Macae - RJ (CRUZ et al., 2013), among others.
For these reasons, Ziller (2006) warns that cases of biological invasions should not be left aside since the impacts tend to increase exponentially over time.

Another factor favoring colonization of tropical forest edges is related to the pioneering behavior of the species A. heterophyllus. According to Santana et al. (2015), tropical forest edges often feature differences and variations from edge to inside edge in relation to micro-environmental conditions, vegetation structure, composition, and biotic interactions. This factor can also make the process of biological invasion easier.

According to IGA, the spatial distribution pattern tending to cluster as calculated for $A$. heterophyllus, according to IGA, might have occurred due to its dispersion syndrome, barochoric in this case, besides of its high abundance in most of the sample units. As stated by Townsend et al. (2010), the simplest evolutionary explanation for a clustered distribution is because organisms aggregate when and where they find suitability of habitats for breeding and survival.

A. heterophyllus distribution tended to cluster within the dominated environment, with the youngest individuals surrounding the adults ones (mother trees). It denotes this species ability to use clustering strategies as an exploration of "safe sites" in most suitable areas, likewise pioneer species in secondary forests dynamics (CHAZDON, 2008).

It is worth mentioning that spatial pattern of species might occur at different scales simultaneously (CAIN et al., 2011). Freitas and Magalhães (2014) deemed three main scales: macro (biogeographical), meso (communities), and micro (individuals within a community). In this study, the microscale was taken into account, which was restricted to the understanding of the edge of the forest fragment invaded by A. heterophyllus.

As reported by Freitas and Magalhães (2014), forest fragmentation can cause changes in the microclimate, increasing the risk of fires that favors tree mortality in a range of up to 100 meters from the edge of a forest fragment, increasing edge effects with direct influence on species diversity. According to Levine (2000), diversity loss reduces a community resistance to biological invasion processes.

The degree of evenness $(\mathrm{J})$ corroborated the $\mathrm{H}^{\prime}$ value, suggesting a low uniformity between the number of individuals out of the number of examined species within the studied plant community (BROWER; ZAR, 1998).

The species showing the highest basal areas were A. heterophyllus $\left(25.97 \mathrm{~m}^{2} \times \mathrm{ha}^{-1}\right)$ and $G$. 
guidonia $\left(6.39 \mathrm{~m}^{2} \times \mathrm{ha}^{-1}\right)$. Dead trees were the eighth position $\left(0,825 \mathrm{~m}^{2} \times \mathrm{ha}^{-1}\right)$. As stated by Martini et al. (2008), the permanence of dead trees inside the forest over time suggests a lesser disturbance in the area. According to Durigan (2009), tree basal area is the best descriptor to characterize structurally a plant community and make comparisons with others because of its direct relation to vegetation biomass and, consequently, influencing microclimate, rainwater interception, as well as shelter and food availability to the fauna.

For Lamprecht (1990), the major combinations under an ecological, silvicultural, and structural aspect for density, frequency, and dominance parameters may be accounted according to the following conditions:

1) High Density, Frequency, and Dominance values stand for the most important species, that is, those species with the highest IV when only analyzed the community horizontal structure (A. heterophyllus).

2) High Density and Frequency represent a typical condition for species with a regular horizontal occurrence (Psychotria leiocarpa).

3) High Density and low Frequency highlight a typical phenomenon for species with site-specific clustering, as for A. heterophyllus and G. guidonia.

Some species found in the study area showed low forest density. This information reinforces the need to adopt effective measures for conservation of these plant populations, which are mostly susceptible to genetic erosion and local extinction (RUSCHEL et al., 2009), as the case of Maytenus obtusifolia.

\section{CONCLUSIONS}

This study reveals the importance of $A$. heterophyllus as an invasive species in the Atlantic Forest ecosystems, being the most important species of the studied community and showing a sitespecific clustering. We showed the urge to adopt conservation measures to establish an effective control of its population.

On the other hand, complementary studies are still necessary to understanding better the mechanisms by which invasion of $A$. hetereophyllus occur in the Atlantic Forest, so that management and control actions against this species could be adopted, especially in fragments where regenerating species can be seen.

\section{ACKNOWLEDGEMENTS}

To FAPERJ - Research Support Foundation of the State of Rio de Janeiro, for the financial support.

RESUMO: A Mata Atlântica encontra-se reduzida a menos de 20\% de sua cobertura original, mas ainda protege um importante patrimônio biológico. A fragmentação da floresta torna o ambiente mais favorável para a ocupação de espécies invasoras. A jaqueira (Artocarpus heterophyllus) foi introduzida no Brasil no século XVII e na segunda metade do século XX houve uma rápida densificação de sua regeneração natural, comprometendo o recrutamento de muitas espécies nativas. Este estudo investigou o impacto da invasão de A. heterophyllus na diversidade e na estrutura do componente arbóreo da borda de um remanescente de Mata Atlântica, no Rio de Janeiro. Duas parcelas do tipo transecto foram alocadas, com $10 \mathrm{~m}$ x $100 \mathrm{~m}\left(1.000 \mathrm{~m}^{2}\right)$, divididas em 10 subparcelas de $10 \mathrm{~m} \mathrm{x} 10 \mathrm{~m}$, com uma amostra total de $2.000 \mathrm{~m}^{2}$. Árvores com diâmetro à altura do peito (DAP) igual ou superior a $5 \mathrm{~cm}$ foram marcadas e o DAP e a altura total foram medidos. Foram obtidos os seguintes parâmetros fitossociológicos: Freqüência, Densidade, Dominância, Valor de Importância (VI) e de Cobertura (VC). No total, 200 espécies de árvores foram amostradas. A invasão foi responsável por mais de $35 \%$ de toda a estrutura do ambiente estudado, obtendo o primeiro lugar em termos de Valor de Importância (VI = $35,62 \%$ ). A baixa riqueza florística parece ter favorecido o processo de invasão de A. heterophyllus na comunidade, mostrando a necessidade de um controle eficaz das espécies para proteção da herança genética nativa.

PALAVRAS-CHAVE: Jaca. Fitossociologia. Estrutura horizontal. Dominância.

\section{REFERENCES}

ABREU, R. C. R.; RODRIGUES, P. J. F. P. Exotic tree Artocarpus heterophyllus Lam. (Moraceae) invades the Brazilian Atlantic Rainforest. Rodriguésia, v. 61, n. 4, p. 677-688, 2010. 
APG III. An update of the Angiosperm Phylogeny Group classification for the orders and families of flowering plants: APG III. Botanical Journal of the Linnean Society, v. 161, n. 2, p. 105-121, 2009. https://doi.org/10.1111/j.1095-8339.2009.00996.x

BERGALLO, H. G.; BERGALLO, A. C.; ROCHA, H. B.; ROCHA, C. F. D. Invasion by Artocarpus heterophyllus (Moraceae) in an island in the Atlantic Forest Biome, Brazil: distribution at the landscape level, density and need for control. Journal of Coastal Conservation, v. 20, n. 3, p. 191-198, 2016. https://doi.org/10.1007/s11852-016-0429-9

BRASIL. Decreto-lei no 9.985, de 18 de julho de 2000. Institui o Sistema Nacional de Unidades de Conservação da Natureza e dá outras providências. Diário Oficial da União, Brasília, DF, 2000.

BROWER, J. E.; ZAR, J. H. Field and laboratory methods for general ecology. 2 ed. Iowa: Wm. C. Brown Publishers, 1998. 273 p.

BUDOWSKI, G. Distribution of tropical American rain forest species in the light of sucessional processes. Turrialba, v. 15, n. 1, p. 40-42, 1965.

BYERS, J. E.; REICHARD, S.; RANDALL, J. M.; PARKER, I. M.; SMITH, C. S.; LONDALE, W. M.; ATKINSON, I. E. A.; SEASTEDT, T. R.; WILLIAMSON, M.; CHORNESKY, E.; HAYES, D. Directing research to reduce the impacts of nonindigenous species. Conservation Biology, v. 16, n. 3, p. 630-640, 2002. https://doi.org/10.1046/j.1523-1739.2002.01057.x

CAIN, M. L.; BOWMAN, W. D.; HACKER, S. D. Ecologia. 1 ed. Porto Alegre: Artmed, 2011. 664 p.

CHAZDON, R. L. Chance and determinism in tropical forest sucession. In: CARSON, W. P.; SCHNITZER, S. A. (eds). Tropical forest community ecology. Chichester: Blackwell Publishing, p. 384-408, 2008.

CIENTEC. Software Mata Nativa 3: Sistema para Análise Fitossociológica, Elaboração de Inventários e Planos de Manejo de Florestas Nativas. Versão 2.0X. Viçosa: Cientec Ltda., 2006.

CRONQUIST, A. An integrated system of classification of flowering plants. 1 ed. New York: Columbia University Press, 1981. 1262 p.

CRUZ, A. R.; SILVA-GONÇALVES, K. C.; NUNES-FREITAS, A. F. Estrutura e florística de comunidade arbórea em duas áreas de Floresta Ombrófila Densa em Macaé, RJ. Rodriguésia, v. 64, n. 4, p. 791-805, 2013. https://doi.org/10.1590/S2175-78602013000400009

CUNHA, A. A.; VIEIRA, M. V.; GRELLE, C. E. V. Preliminary observations on habitat, support use and diet in two non-native primates in an urban Atlantic forest fragment: The capuchin monkey (Cebus sp.) and the common marmoset (Callithrixjacchus) in the Tijuca forest, Rio de Janeiro. Urban Ecosystems, v. 9, n. 4, p. 351-359, 2006. https://doi.org/10.1007/s11252-006-0005-4

DEAN, W. A ferro e fogo: a história e a devastação da Mata Atlântica brasileira. 1. ed. São Paulo: Companhia das Letras, 1996. 484 p.

DURIGAN, G. Estrutura e diversidade de florestas tropicais. In: MARTINS, S. V. (org). Ecologia de Florestas Tropicais do Brasil. 2. ed. Viçosa: Editora UFV, 2009. 371 p.

FABRICANTE, J. R.; ARAUJO, K. C. T.; ANDRADE, L. A.; FERREIRA, J. V. A. Invasão biológica de Artocarpus heterophyllus Lam. (Moraceae) em um fragmento de Mata Atlântica no Nordeste do Brasil: impactos sobre a fitodiversidade e os solos dos sítios invadidos. Acta Botanica Brasilica, v. 26, n. 2, p. 399407, 2012. https://doi.org/10.1590/s0102-33062012000200015 
FLORA BRASIL. 2015. LISTA de espécies da flora do Brasil. Available in: http://floradobrasil.jbrj.gov.br/jabot/listaBrasil/PrincipalUC/PrincipalUC.do;jsessionid=79819F05DBBDC5C5 9B0FF982F3A58D25 Accessed in: 17 July 2015.

FREITAS, W. K.; MAGALHÃES, L. M. S. Florística, diversidade e distribuição espacial das espécies arbóreas de um trecho de Floresta Estacional Semidecidual da Serra da Concórdia, RJ. Floresta, v. 44, n. 2, p. 259-270, 2014. https://doi.org/10.5380/rf.v44i2.30661

HURLBERT, S. The nonconcept of species diversity: a critic and alternative parameters. Ecology, v. 52, n. 4, p. 577-586, 1971.

IBGE. INSTITUTO BRASILEIRO DE GEOGRAFIA E ESTATÍSTICA. Manual técnico da vegetação brasileira. Fundação Instituto Brasileiro de Geografia e Estatística. Rio de Janeiro: IBGE, 1992. 92 p.

KANASHIRO, M. Plantas exóticas ameaçam biodiversidade. Ciência e Cultura, v. 55, n. 3, p. 49-49, 2003.

KEANE, R. M.; CRAWLEY, M. J. Exotic plant invasions and the enemy release hypothesis. Trends in Ecology \& Evolution, v. 17, n. 4, p. 164-170, 2002. https://doi.org/10.1016/S0169-5347(02)02499-0

LAKE, J. C.; LEISHMAN, M. R. Invasion success of exotic plants in natural ecosystems: the role of disturbance, plant attributes and freedom from herbivores. Biological Conservation, v. 117, n. 2, p. 215-226, 2003. https://doi.org/10.1016/S0006-3207(03)00294-5

LAMPRECHT, H. Silvicultura nos trópicos: Ecossistemas florestais e respectivas espécies arbóreas possibilidades e métodos de aproveitamento sustentado. Eschborn: Instituto de Silvicultura da Universidade Gottingen, República Federal da Alemanha, 1990. 343 p.

LEVINE, J. M. Species Diversity and Biological Invasions: Relating Local Process to Community Pattern. Science, v. 288, n. 5467, p. 852-854, 2000. https://doi.org/10.1126/science.288.5467.852

LIMA, A. R.; CAPOBIANCO, J. P. R. Mata Atlântica: avanços legais e institucionais para a sua conservação. São Paulo: Instituto Socioambiental, 1997. 111 p (Documentos ISA no).

MAGALHÃES, L. M. S.; FREITAS, W. K. Composição florística e similaridade de fragmentos florestais com diferentes idades, na região serrana do Rio de Janeiro. Revista de Ciências Agrárias, v. 56, n. 3, p. 212-220, 2013. https://doi.org/10.4322/rca.2013.031

MAGALHÃES, L. M. S.; FREITAS, W. K.; RESENDE, A. S.; PINHEIRO, M. A. S.; GOMES, E. De provedora a invasora? Como se transformou a jaqueira em um grave problema ambiental para as unidades de conservação da cidade do Rio de Janeiro. In: Biodiversidade Carioca: Segredos Revelados. Rio de Janeiro: Technical Books Editora, 2015. p. 308-326.

MARTINI, A. M. Z.; LIMA, R. A. F.; FRANCO, G. C. D.; RODRIGUES, R. R. The need for full inventories of tree modes of disturbance to improve forest dynamics comprehension: An example from a semideciduous forest in Brazil. Forest Ecology and Management, v. 255, p. 1479-1488, 2008.

https://doi.org/10.1016/j.foreco.2007.11.004

MCGINNIES, W. G. The relationship between frequency index and abundance as applied to plant populations in a semi-arid region. Ecology, v. 15, n. 3, p. 263-282, 1934. https://doi.org/10.2307/1932468

MELlO, J. H. F.; MOULTON, T. P.; RAÍCES, T. P.; BERGALLO, H. G. About rats and jackfruit trees: modeling the carrying capacity of a Brazilian Atlantic Forest spiny-rat Trinomys dimidiatus (Günther, 1877) Rodentia, Echimyidae - population with varying jackfruit tree (Artocarpus heterophyllus L.) abundances. Brazilian Journal of Biology, v. 75, n. 1, p. 208-215, 2015. https://doi.org/10.1590/1519-6984.11613 
MUELLER-DOMBOIS, D.; ELLENBERG, H. Aims and methods of vegetation ecology. 1. ed. New York: John Wiley \& Sons, 1974. 547 p.

MYERS, N.; MITTERMEIER, R. A.; MITTERMEIER, C. G.; FONSECA, G. A. B., RYLANDS, A. B., BRANDON, K. Uma breve história da conservação da biodiversidade no Brasil. Megadiversidade, Belo Horizonte, v. 1, n. 1, p. 14-21, 2005.

OLIVEIRA-FILHO, A. T.; FONTES, M. A. Patterns of floristic differentiation among Atlantic Forest in Southeastern Brazil and the influence of climate. Biotropica, v. 32, n. 4b, p. 793-809, 2000. https://doi.org/10.1646/0006-3606(2000)032[0793:POFDAA]2.0.CO;2 https://doi.org/10.1111/j.1744-7429.2000.tb00619.x

PARKER, I. M.; SIMBERLOFF, D.; LONSDALE, W. M.; GOODELL, K.; WONHAM, M.; KAREIVA, P. M.; WILLIAMSON, M. H.; VON HOLLE, B.; MOYLE, P. B.; BYERS, J. E.; GOLDWASSER, L. Impact: toward a framework for understanding the ecological effects of invaders. Biological Invasions, Knoxville, v. 1, n. 1, p. 3-19, 1999. https://doi.org/10.1023/A:1010034312781

PEREIRA, V. J.; KAPLAN, M. A. C. Artocarpus: um gênero exótico de grande bioatividade. Floresta \& Ambiente, Seropédica, v. 20, n. 1, p. 1-15, 2013.

PYSEK, P. On the terminology used in plant invasion studies. In: PYSEK, P.; PRACH, K.; REJMANEK, M.; WADE, M. (eds). Plant invasions: general aspects and special problems. Amsterdam: SPB, p. 71-81, 1995.

RIBEIRO, M. C.; METZGER, J. P.; MARTENSEN, A. C.; PONZONI, F. J.; HIROTA, M. M. The Brazilian Atlantic Forest: how much is left, and how is the remaining forest distributed? Implications for conservation. Biological Conservation, v. 142, n. 6, p. 1.144-1.156, 2009.

RUSCHEL, A. R.; GUERRA, M. P.; NODARI, R. O. Estrutura e composição florística de dois fragmentos da Floresta Estacional Decidual do Alto Uruguai, SC. Ciência Florestal, Santa Maria, v. 19, n. 2, p. 225-236, 2009. https://doi.org/10.5902/19805098413

SANTANA, C. A. A.; FREITAS, W. K.; MAGALHÃES, L. M. S. Estrutura e similaridade em florestas urbanas na região metropolitana do Rio de Janeiro. Interciencia, v. 40, n. 7, p. 479-486, 2015.

SANTOS, A. R.; BERGALLO, H. G.; ROCHA, C. F. D. Paisagem urbana alienígena. Ciência Hoje, v. 41, p. 68-70, 2008.

SAX, D. F.; BROWN, J. H. The Paradox of Invasion. Global Ecology \& Biogeography, v. 9, n. 5, p. 363-372, 2000. https://doi.org/10.1046/j.1365-2699.2000.00217.x

STEHMANN, J. R.; FORZZA, R. C.; SALINO, A.; SOBRAL, M.; COSTA, D. P.; KAMINO, L. H. Y. Plantas da Floresta Atlântica. 1. ed. Rio de Janeiro: Jardim Botânico do Rio de Janeiro, 2009. 516 p.

TOMIAZZI, A. B.; VILLARINHO, F. M.; MACEDO, R. L. G.; VENTURIN, N. Perfil dos visitantes do Parque Natural Municipal do Mendanha, município do Rio de Janeiro, RJ. Cerne, Lavras, v. 12, n. 4, p. 406411, 2006.

TOWNSEND, C. R.; BEGON, M.; HARPER, J. L. Fundamentos em Ecologia. 3 ed. Porto Alegre: Artmed, 2010. $576 \mathrm{p}$.

WILLIAMS, K. J.; FORD, A.; DAN, F. R.; SILVA, N.; MITTERMEIER, R.; BRUCE, C.; LARSEN, F. W.; MARGULES, C. Chapter 16: Forests of East Australia: the 35th biodiversity hotspot. In: ZACHOS, F. E., HABEL, J. C. (eds). Biodiversity hotspots: distribution and protection of conservation priority areas. Heidelberg: Springer, p. 295-310, 2011. https://doi.org/10.1007/978-3-642-20992-5_16 
ZILLER, S. R.; GALVÃO, F. A Degradação da estepe gramíneo lenhosa no Paraná por contaminação biológica de Pinus elliotti e P. taeda. Floresta, Curitiba, v. 32, n. 1, p. 41-47, 2002.

ZILLER, S. R. Espécies exóticas da flora invasoras em unidades de conservação. In: CAMPOS, J. B.; TOSSULINO, M. G. P.; MÜLLER, C. R. C. (org). Unidades de conservação: ações para valorização da biodiversidade. Curitiba: Instituto Ambiental do Paraná, p. 34-52, 2006. 